\title{
The Feasibility of Downsizing a 1.25 Liter Normally Aspirated Engine to a 0.43 Liter Highly Turbocharged Engine
}

\author{
William P. Attard, Steven Konidaris, Elisa Toulson and Harry C. Watson \\ University of Melbourne
}

Copyright @ 2007 SAE International

\begin{abstract}
In this paper, performance, efficiency and emission experimental results are presented from a prototype 434 $\mathrm{cm}^{3}$, highly turbocharged (TC), two cylinder engine with brake power limited to approximately $60 \mathrm{~kW}$. These results are compared to current small engines found in today's automobile marketplace. A normally aspirated (NA) 1.25 liter, four cylinder, modern production engine with similar brake power output is used for comparison. Results illustrate the potential for downsized engines to significantly reduce fuel consumption while still maintaining engine performance. This has advantages in reducing vehicle running costs together with meeting tighter carbon dioxide $\left(\mathrm{CO}_{2}\right)$ emission standards.
\end{abstract}

Experimental results highlight the performance potential of smaller engines with intake boosting. This is demonstrated with the test engine achieving 25 bar brake mean effective pressure (BMEP). Results are presented across varying parameter domains, including engine speed, compression ratio $(C R)$, manifold absolute pressure (MAP) and lambda $(\lambda)$. Engine operating limits are also outlined, with spark knock highlighted as the major limitation in extending the operating limits for this downsized engine.

\section{INTRODUCTION}

In recent years there have been growing concerns regarding oil shortages which have led to escalating oil prices. In addition, anxiety over global warming has prompted car manufacturers to agree to greenhouse emission targets, including most recently Californian standards [1]. Other legislating bodies are sure to follow this lead with increasingly stringent targets. As a result of these issues, spark ignition (SI) engines in their current form will need significant changes to meet future requirements. One technically feasible option is smaller downsized engines with enhanced power $[2,3,4]$. These engines could be used in the near term, to reduce both carbon emissions and fuel consumption in passenger vehicles.

Engines found in compact sized passenger vehicles in today's automobile marketplace are considered small, but are usually more than twice the capacity of the test engine. Furthermore, the technology needed to replace these larger engines with smaller downsized units already exists in NA versions, which are commonly mass produced for motorcycle and other applications. Applying turbocharger technology to smaller engines provides an economically viable solution in the near term prior to the implementation of alternative powertrain technology (fuel cell, electric or hybrid). This has significant relevance to manufacturers, who continue to strive for swept capacity reductions, while maintaining performance, improving efficiency and meeting emission regulations. This research parallels steps already present in the market place for diesel engines $[5,6]$ and is essential in giving direction to the development of smaller gasoline engines, which will be needed to meet both the world's future powertrain and environmental requirements. This work differs from the Japanese Kei (K) class of passenger vehicles, which feature similar capacity, but reduced performance engines fitted to microcars, as found in the Smart vehicle range [7]. The presented research focuses on replacing engines found in compact sized regular passenger vehicles.

\section{OBJECTIVES}

The original intent of this development program was to achieve success in Formula SAE competition using a specifically designed and developed downsized engine. However, from the research and development process, more significant findings concerning small engines have been discovered [8-14]. This paper focuses on the feasibility of replacing larger engines found in passenger vehicles with smaller downsized versions. Specifically, the objectives are to:

$>$ Highlight the performance potential and operating limits of downsized engines $\left(\sim 500 \mathrm{~cm}^{3}\right)$ for the purpose of replacing larger engines found in automobiles

$>$ Explore the effects on performance, efficiency and emissions for the downsized test engine across engine speed, CR, MAP and $\lambda$ domains

$>$ Highlight the factors limiting performance for downsized engines

$>$ Define the extent or the swept capacity reduction ratio to which larger engines can be reliably downsized while still maintaining equal power

$>$ Explore the feasibility of replacing a 1.25 liter automobile engine and the resulting vehicle effects on performance, efficiency and emissions 


\section{TEST ENGINE}

The test engine used in experiments was specifically designed and developed at the University of Melbourne for use in Formula SAE. The Formula rules limit the intake airflow by requiring the use of a $20 \mathrm{~mm}$ diameter orifice, which limits maximum brake power to approximately $60 \mathrm{~kW}$. Consequently, the test engine was optimized to operate at the flow restricted condition.

The $434 \mathrm{~cm}^{3}$ twin cylinder in-line arrangement featured double overhead camshafts and four valves per cylinder. Most of the engine components were specially cast or machined from billets. Further detail concerning the test engine is documented [8-14], with general specifications given in Table 1. Figure 1 displays the final TC version while Figure 2 highlights a sectional view of the engine design.
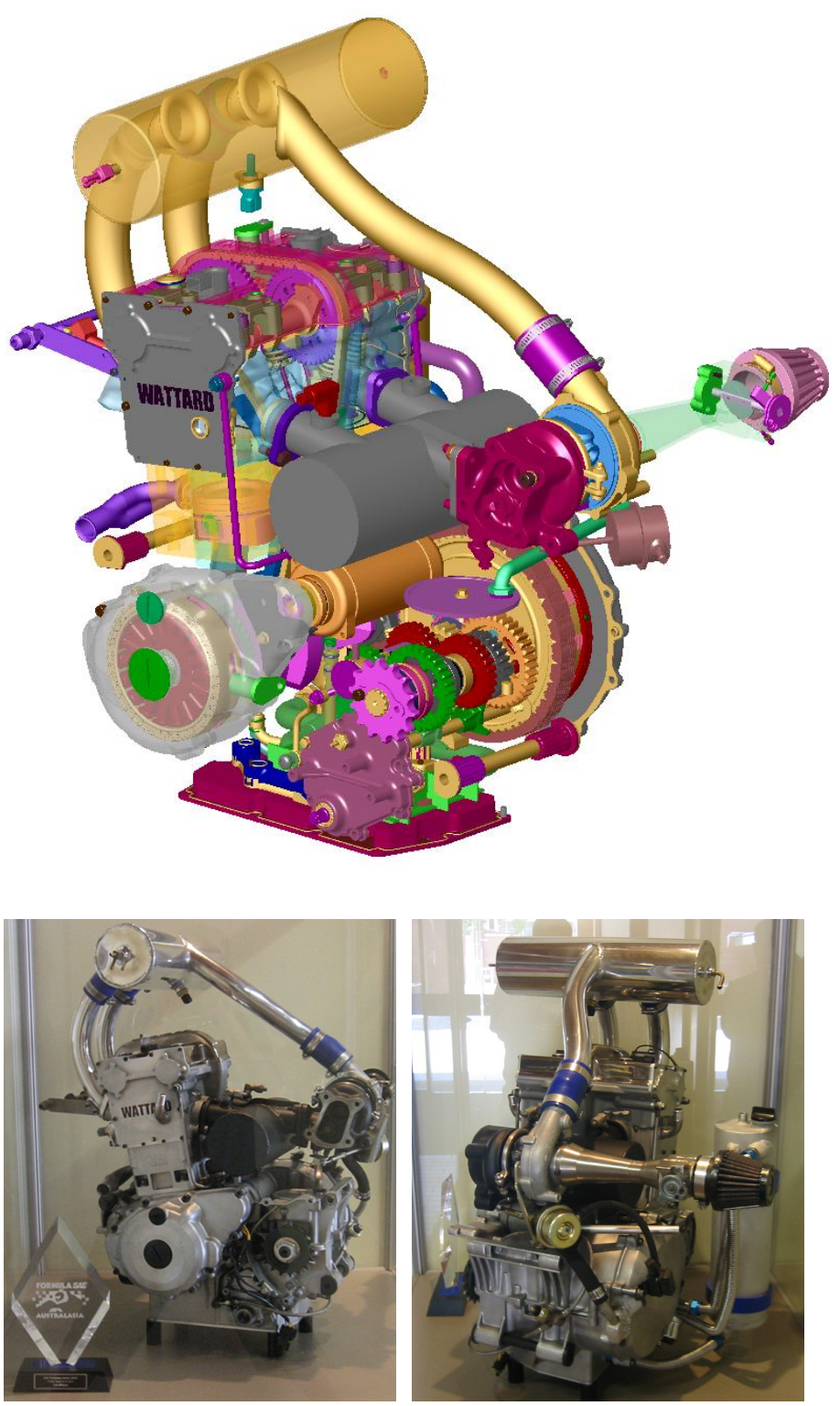

Figure 1: The UniMelb 'WATTARD' engine. (Upper): CAD image. (Lower): Final TC version.
Table 1: Specifications for the UniMelb 'WATTARD' engine.

\begin{tabular}{|ll|}
\hline ENGINE & UniMelb 'WATTARD' (Prototype) \\
TYPE & In-line twin, \\
& 4 stroke SI, \\
& Liquid-cooled, \\
& Aluminum head/ barrel/ crankcase \\
& Integral clutch/ transmission \\
& $433.8 \mathrm{~cm}^{3}$ \\
CAPACITY & $69 \times 58 \mathrm{~mm}$ \\
BORE X STROKE & Unequal $\left(0^{\circ}, 180^{\circ} \mathrm{CA}\right)$ \\
FIRING ORDER & $9-13: 1$ with piston modification \\
COMPRESSION RATIO & Pent roof central spark plug \\
COMBUSTION CHAMBER & $8-\mathrm{valve} \mathrm{DOHC}$ \\
VALVE ACTUATION & IVO $24^{\circ}$ BTDC \\
VALVE TIMING & IVC $72^{\circ}$ ABDC \\
& EVO $57^{\circ}$ BBDC \\
& EVC $9^{\circ}$ ATDC \\
INDUCTION & TC Sequential PFI, \\
FUEL & $\varnothing 20$ mm flow restriction \\
ENGINE MANAGEMENT & $98-R O N$ pump gasoline \\
TURBOCHARGER & Garrett GT-12, \\
TRANSMISSION & EMS controlled internal wastegate \\
& 3 speed constant mesh \\
\hline
\end{tabular}

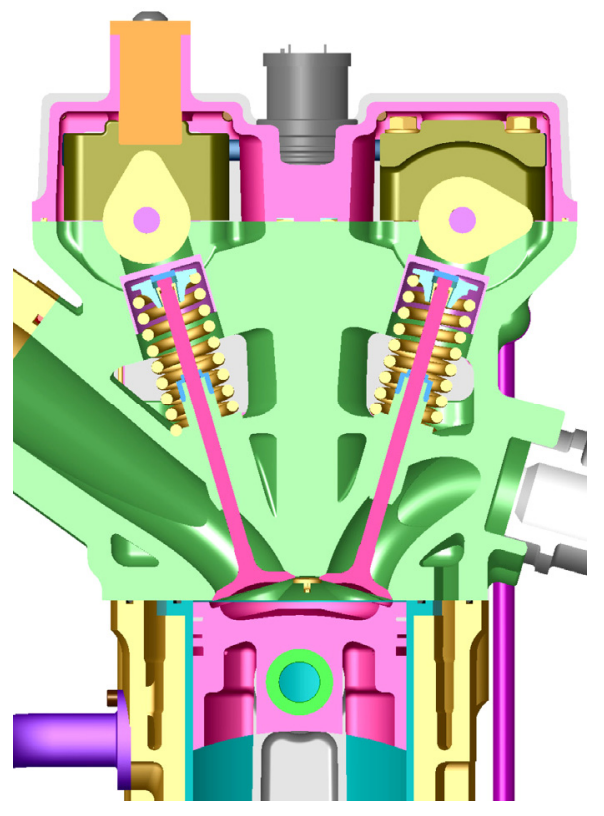

Figure 2: Engine sectional view, highlighting the barrel, cylinder head, piston and piston pin end of the connecting rod.

\section{EXPERIMENTS}

A detailed description of the experimental setup has previously been documented $[8,12]$, with a schematic shown in Figure 3. It should be noted that all brake data presented in this paper corresponds to the performance at the gearbox output shaft and not at the crankshaft. This is due to the engine design featuring an integral clutch and transmission within the crankcase. Performance at the crankshaft is expected to be marginally higher, due to the reduction in parasitic losses associated with driving the transmission components. 


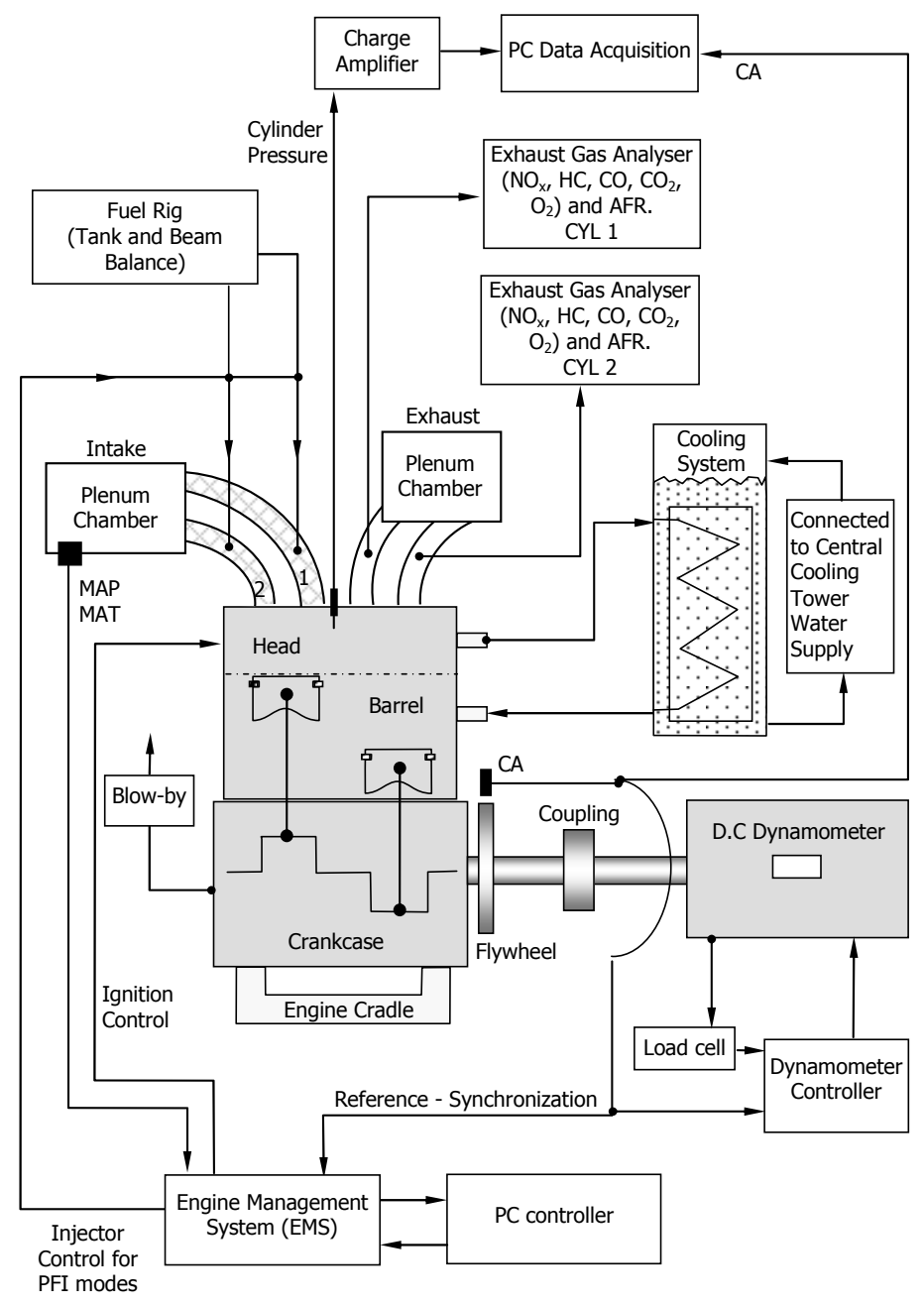

Figure 3: Experimental set-up illustrating the basic schematic layout of the engine, including controllers, sensors and data acquisition systems.

Experiments were completed using Shell Optimax, a 98RON pump gasoline with specifications previously defined $[8,12]$. Testing commenced at the highest CR which was limited to $13: 1$. This was the highest achievable with a flat top piston in the pent roof combustion chamber. The decision to use a flat top piston was based on manufacturability, with simple machining processes allowing reductions in CR. Hence, variations ranging from 9-13:1 were made possible through piston crown modifications to a set of custom forged pistons. It is noted that squish areas around the periphery of the chamber were maintained to minimize the differing effects of turbulence and resulting combustion effects for varying CRs. However, changes to the turbulent length scale were inevitable due to the required combustion chamber dish depth to achieve the desired CR.

The ignition tuning strategy involved finding the minimum spark advance for maximum brake torque (MBT-ST) or in the case when ignition timing was knock limited, the knock limited spark timing (KL-ST). The first stage of knock control relied on traditional methods involving varying degrees of spark retard and/or fuel enrichment [15], albeit with the penalty of increased fuel consumption.
The fuel tuning strategy varied as the original intended Formula application did not govern specific emissions. Hence, $\lambda$ varied depending on the load condition as stoichiometric air-fuel ratio (AFR) for three-way catalyst (TWC) operation was not required. Lean and stoichiometric mixtures were targeted at light and medium loads to improve efficiency and reduce fuel consumption. Richer mixtures were used at heavier load conditions associated with achieving maximum brake performance. This improved brake output and provided component protection due to the reduced combustion temperatures. Further details outlining the tuning strategy are given in Table 2 .

Table 2: Engine tuning strategy over the varying test conditions.

\begin{tabular}{|c|c|c|c|}
\cline { 2 - 4 } \multicolumn{1}{c|}{} & \multicolumn{3}{c|}{ LOAD CONDITION } \\
\cline { 2 - 4 } \multicolumn{1}{c|}{} & Light & Medium & Heavy \\
\hline BMEP $(\mathbf{k P a})$ & $<300$ & $300-600$ & $>600$ \\
\hline Targeted $\lambda$ & $1.1-1.2$ & 1 & 0.9 \\
\hline Spark Timing & MBT & MBT & MBT or KL \\
\hline PFI Injection Timing & MBT & MBT & MBT \\
\hline
\end{tabular}

Experiments were completed without intake air cooling (intercooling) as manifold air temperatures (MAT) rarely exceeded $70^{\circ} \mathrm{C}$ as shown in Figure 4. This was due to the large aluminum manifold surface area and high turbocharger efficiencies. However, intake temperatures are shown to increase for rising boost levels. Developing the engine without an intercooler gave mass, packaging and cost benefits together with simplifying the complexity of the intake system. Although power increases are associated with intercooling $[16,17]$, these benefits were not large for this particular setup due to the limited airflow, with improvements largely associated with possible CR increases due to likely knock reductions [18]. However, the expected temperature reductions were not large when considering the boosted intake temperatures and intercooler efficiencies.

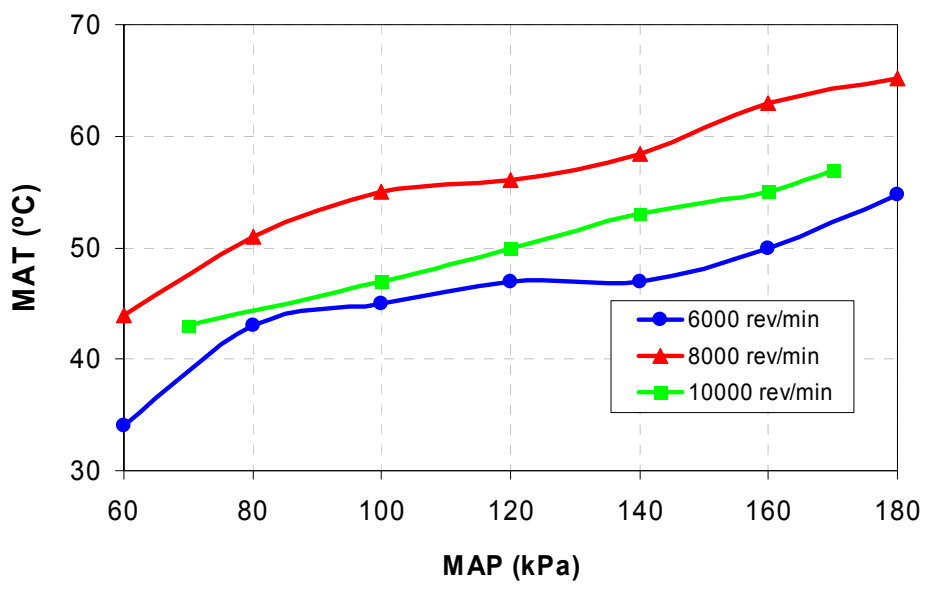

Figure 4: Intake air temperatures measured in the plenum chamber for varying engine speeds and MAP. 


\section{OPERATING LIMITS}

The knock (KL) and damage limit (DL), previously published by Rothe [19], were used to quantify knock limits to ensure engine reliability, with the knock amplitude (KA) defined as the zero to peak pressure of the high pass filtered cylinder pressure.

$$
\begin{aligned}
& >\mathrm{KL} \quad 1 \% \text { cycles with } \mathrm{KA}>4 \text { bar } \\
& >\mathrm{DL} \quad 1 \% \text { cycles with } \mathrm{KA}>20 \text { bar }
\end{aligned}
$$

Figure 5 displays the knock and airflow limitations as functions of engine speed, MAP and CR, found from experimental testing. It is noted that the test engine was optimized to operate at the flow restricted intake condition for Formula SAE application. Consequently at wide open throttle (WOT), the cross plots show varying MAP levels for engine speed increases. This is initially caused by inadequate turbocharger air supply, followed by choked flow through the intake restriction. Once the choked flow operating condition was reached and verified, the turbocharger wastegate valve was manipulated by the ECU in order to minimize losses [11]. The WOT condition for a given CR is denoted as the performance limit $(\mathrm{PL})$, highlighted by the dashed line in Figures 5, 10 and 11.

The cross plots of Figure 5 have been constructed from multi-CR experimental data points, gathered by incrementally varying the $C R$ to values dictated by the knock severity. These CR values included 9.6, 10, 11, and 13. Resulting piston crown and combustion chamber geometry associated with each $\mathrm{CR}$ is displayed in Figure 6. The cross hatched areas in Figure 5, indicate domains where engine operation was $\mathrm{KL}$ but could be controlled via EMS tuning strategies to avoid the DL. The shaded areas in plots indicate where engine operation was not possible due to airflow limitations or heavy knock exceeding the DL.

From Figure 5, knock severity is shown to be highest at $6000 \mathrm{rev} / \mathrm{min}$, corresponding to the highest achieved MAP of $270 \mathrm{kPa}$. High knock intensities were likely at mid range speeds due to the higher levels of boost needed to maintain maximum airflow due to the flow restriction. Initially, a CR reduction from 11 to 9.6, coupled with mild levels of knock compensation was used to ensure the DL was avoided in this particular region. However, this compromised power and efficiency at lower MAP levels and therefore the CR was later increased to 10 to reduce these effects. This increased knock intensities which were counteracted with increasing levels of knock compensation as highlighted in Figure 5. However, running on the edge of the DL was limited to this particular operating point. This ensured the choked flow objectives for Formula SAE competition could be achieved over the widest possible speed range, with reduced compromises in power and efficiency at lower MAP levels.

Experiments highlight that high rates of combustion, as a consequence of spark knock, were the most dominant factor in limiting the performance of this downsized engine.
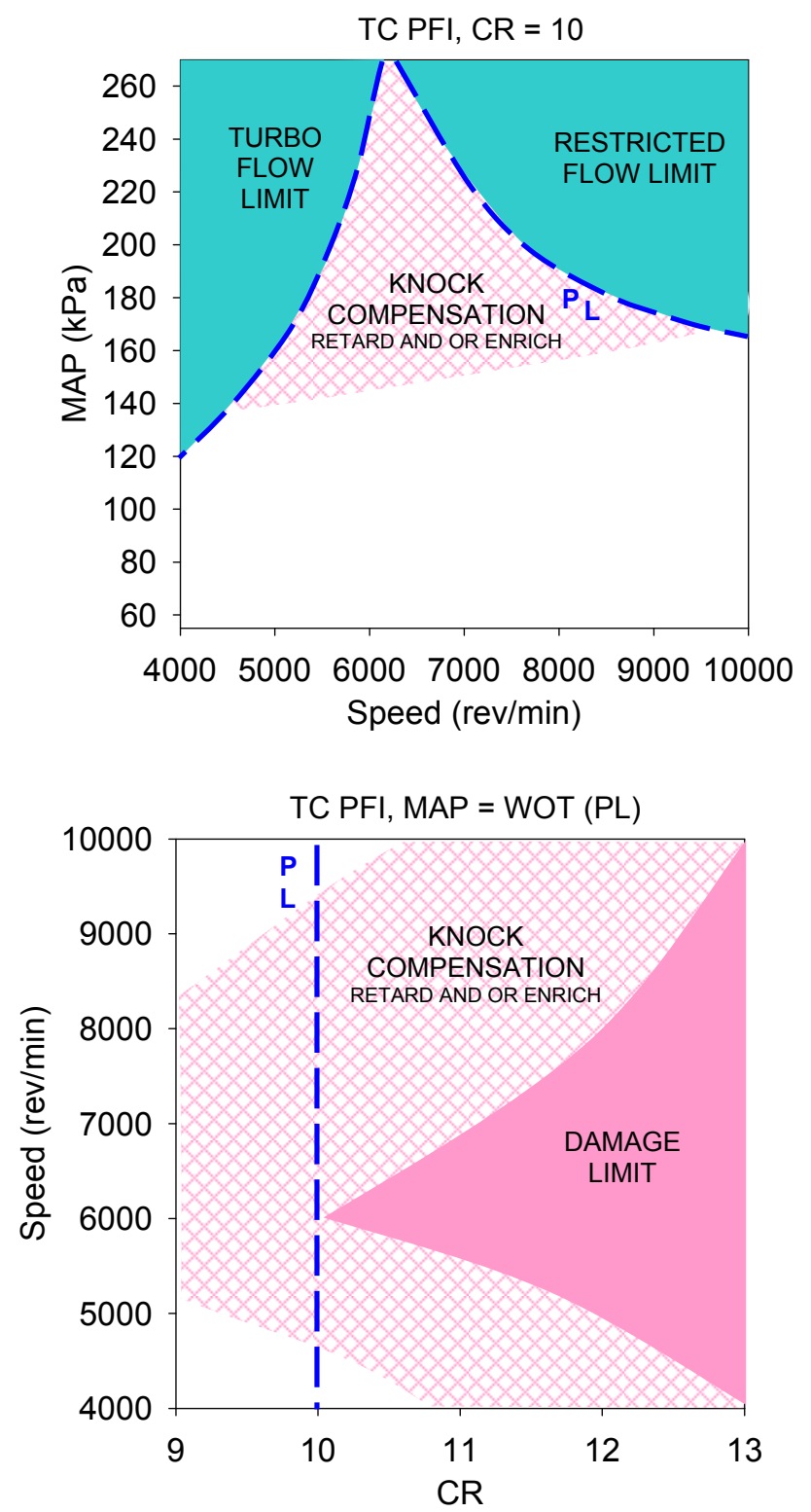

Figure 5: Knock limitations versus engine speed, MAP and CR. Engine optimized for the flow restricted condition. Cross hatched areas indicate operation with spark retard and/or fuel enrichment to compensate for knock. Shaded areas indicate non operation due to knock levels above the DL or limited airflow. PL is the performance limit line defined at WOT for a given $\mathrm{CR}$.

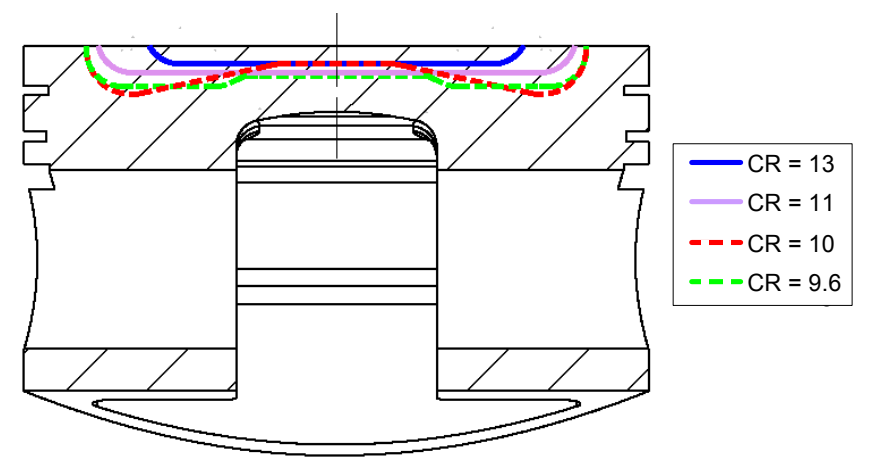

Figure 6: Piston sectional view illustrating the combustion chamber geometry for varying CRs. Combustion chamber geometry is symmetrical about the piston central axis. 
Spark knock effects on in-cylinder pressures with varying intensities are shown in Figure 7 , over four consecutive cycles. These high knock intensities had detrimental effects on piston and piston ring components as displayed in Figure 8.

Consequently, experimental results show that knock limits determine the extent to which engine capacity can be reduced, while still maintaining performance equal to that of larger counterparts. Extending the knock limits using modern knock preventative strategies could allow increases in $\mathrm{CR}$ and/or MAP, which would improve performance and allow further capacity reductions. These strategies could include direct injection (DI), exhaust gas recirculation (EGR), intake charge cooling (intercooling and/or fuel evaporative), combustion enhancement and/or variable valve timing (VVT) [3,15,18,20-22]. However, these strategies were not implemented during experiments due to their added complexity and well documented effects.

With spark knock highlighted as the major limitation, strategies used in experiments to extend the operating limits are now described with the effects documented. Experiments found that spark retard and/or fuel enrichment can be used as methods of knock control for up to 1-2 CR points, depending on the knock severity. However, the increased efficiency due to the possible $\mathrm{CR}$ and/or MAP increases were found to be offset by the increased enrichment and less optimum spark timing.

The heavy fuel enrichment near WOT could also cause high piston and cylinder wear rates associated with cylinder bore wash [23], however this effect was not witnessed in experiments. Emission reductions at WOT would also be difficult to achieve as the heavy enrichment would significantly reduce TWC efficiencies, limiting the exhaust after treatment effectiveness. However, there is no requirement for emission control near WOT in present standards so concern is about avoiding catalyst overheating with mixtures just rich of stoichiometric. Thus the present control strategy should be satisfactory as only low boost levels are needed over the New European Drive Cycle (NEDC) as shown later in this paper, where engine operation is closer to stoichiometric conditions.

Trends from the knock limits also confirm that for a given CR and MAP condition, knock is less susceptible at higher engine speeds $[8,12,19,24,25]$. The reduced knock likelihood is a consequence of the increased flame speeds within the combustion chamber, which consume the unburnt mass in the end-gas region more quickly. Increasing flame speeds decreases the knock likelihood due to the reduced end-gas residence time within the combustion chamber. The effects on flame velocities for varying engine speeds for this particular engine are documented $[8,14]$. Other factors involving the engine design and configuration have also been documented to extend the operating limits when compared to production engines with larger bore sizes $[8,9,14]$.
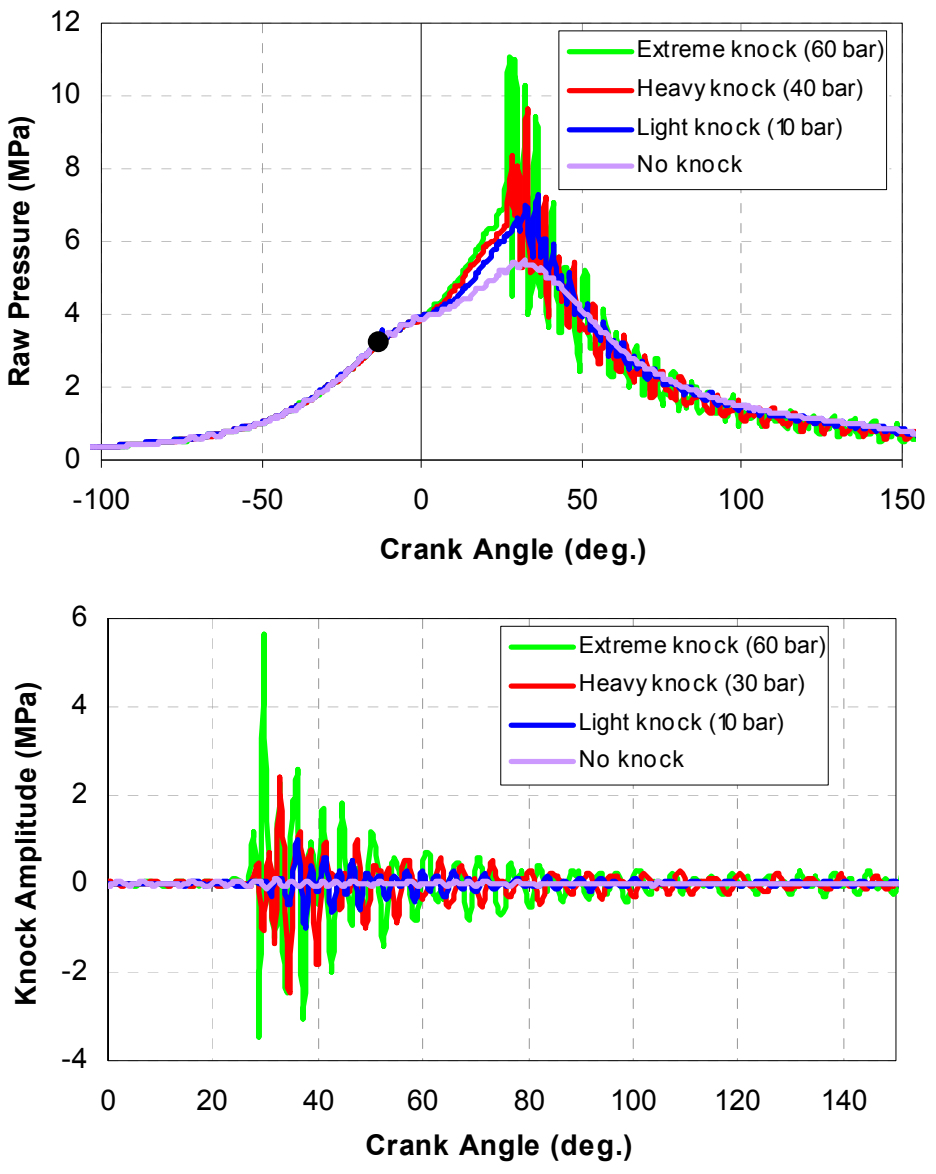

Figure 7: The effects of spark knock on in-cylinder pressures across four consecutive cycles. $6000 \mathrm{rev} / \mathrm{min}, 220 \mathrm{kPa}$ MAP.

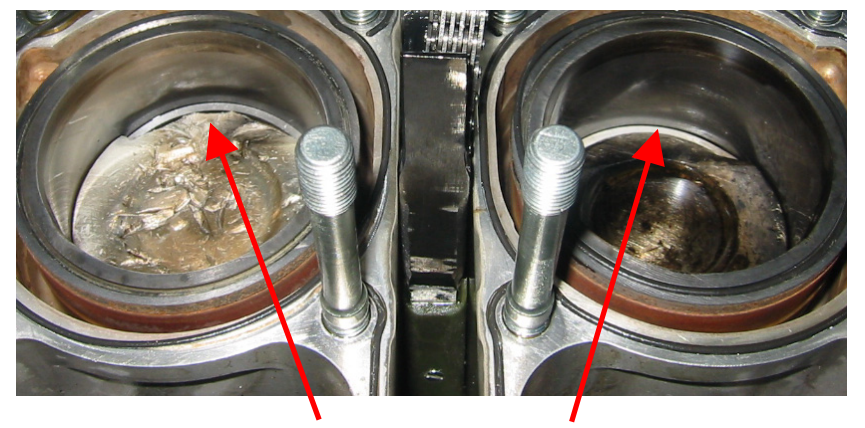

INLET SIDE PISTON LAND FAILURE

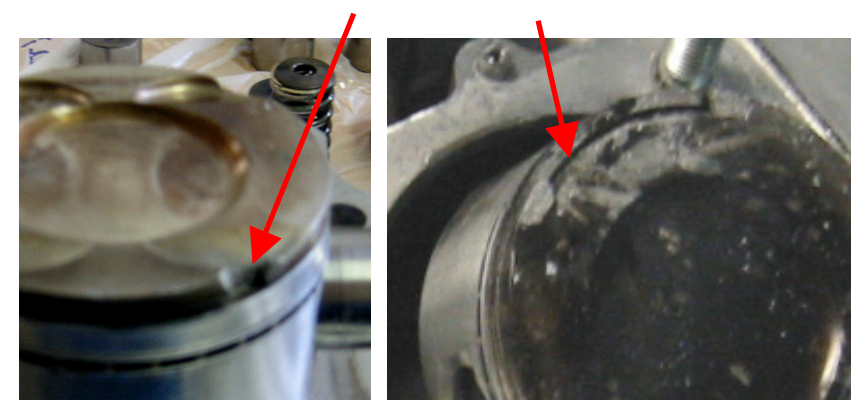

Figure 8: Adverse effects of heavy knock in the end-gas region above the DL. (Upper): Simultaneous inlet side piston land failure in both cylinders. (Lower): Further inlet side failures after increased piston oil cooling, directed towards the piston intake underside. 


\section{EXPERIMENTAL RESULTS}

Figures 9 to 11 present performance, efficiency and emission experimental results for varying engine speed, MAP and $\lambda$ parameters. Results are presented at the highest useable CR of 10 defined by Figure 5 . Contour plots (Figures 10 and 11) are displayed with shaded areas, indicating where engine operation was not possible due to the previously described limitations. However, contours are extrapolated into these regions so the reader can deduce expected results if the limitations were removed.

From Figure 10, extrapolation contours demonstrate that the test engine is capable of producing approximately 200 kW per liter, thus highlighting the performance potential for downsized engines with the aid of intake boosting. Results show brake power increases for rising engine speeds and MAP. Power increases related to MAP are shown to be directly proportional to rising BMEP, largely attributed to increased air consumption, as shown by the volumetric efficiency $\left(\eta_{\mathrm{VO}}\right)$. Peak BMEP values occur at mid range speeds corresponding to the tuned intake tract length, also highlighted by the $\eta_{\text {VoL }}$ contours. The BMEP falls quickly above the tuned intake speed as the induced airflow and mechanical efficiency decrease due to the increased frictional losses associated with the higher speeds.

Furthermore, the $\eta_{\mathrm{VOL}}$ contour lines in Figure 10 begin to diverge as the MAP is increased past atmospheric conditions. This is associated with decreasing air charge density, which is caused by the rising MAT associated with the turbocharger compressor delivery as previously described (Figure 4).

Peak thermal efficiencies $\left(\eta_{\mathrm{TH}}\right)$ were recorded near the $100 \mathrm{kPa} \mathrm{MAP}, 5000 \mathrm{rev} / \mathrm{min}$ region as a result of improved mechanical efficiencies (reduced pumping losses) together with fuel mixtures which were nearer to stoichiometric. Further improvements were expected for rising boost levels as pumping losses continue to decrease $[18,26]$. However, these results did not eventuate, largely due to the excessive increases in fuel enrichment and spark retard (Figure 10 - Lower) needed to control knock for the rising MAP. Furthermore, the higher cycle pressures and hence temperatures associated with the rising MAP cause higher levels of dissociation and heat losses, which also reduces $\eta_{\mathrm{TH}}$.

Figures 9 and 11 display engine out emission results. It is noted that governments regulate emission control in terms of vehicle mass out emissions relative to distance traveled $(\mathrm{g} / \mathrm{km}$ or $\mathrm{g} / \mathrm{mi})$ [27]. Hence, smaller vehicles fitted with smaller engines generally have emission benefits, requiring reduced after treatment clean-up to satisfy regulations. Nevertheless, engine out raw concentrations (Figure 9) and brake specific emissions (Figure 11) are presented. For comparative purposes, brake specific emissions have been corrected to stoichiometric conditions [8], to allow for the drive cycle analysis outlined later in this paper.
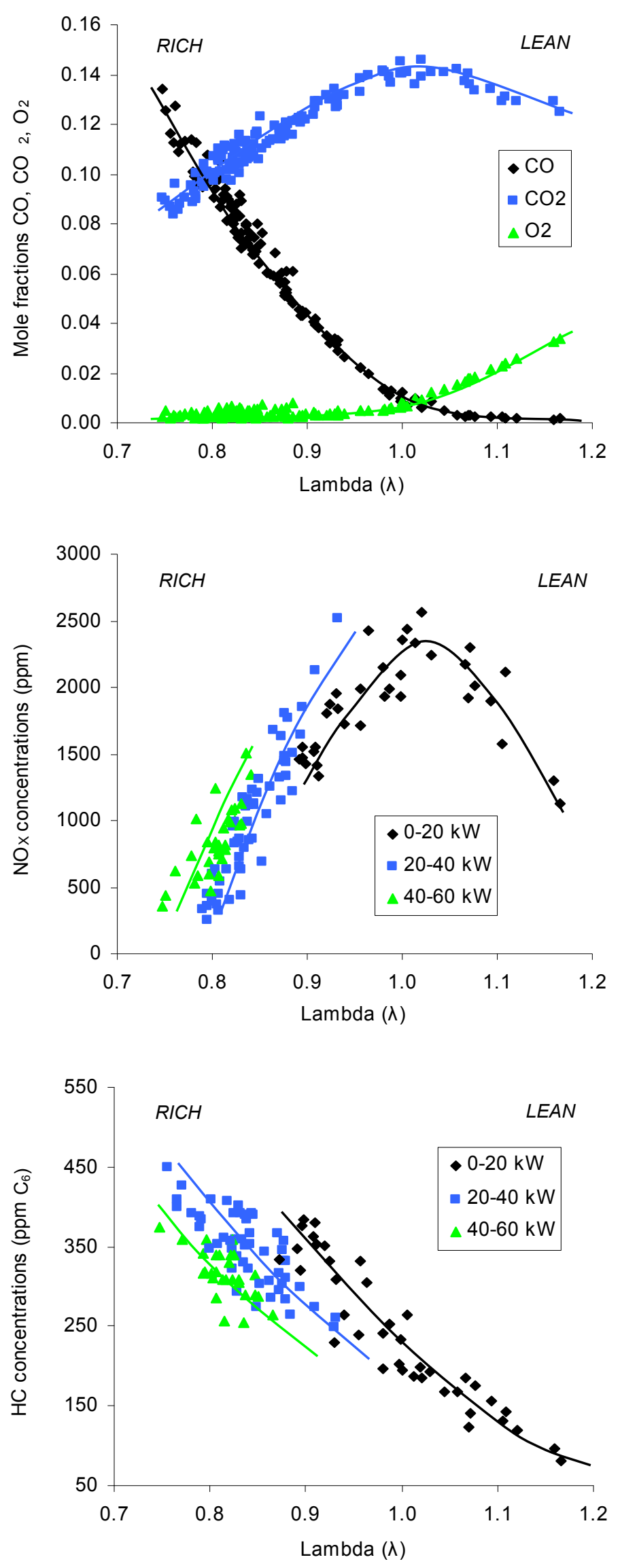

Figure 9: TC-PFI engine out raw emission concentrations for varying $\lambda$ and power outputs, achieved with engine speed and MAP variation, $C R=10$. 

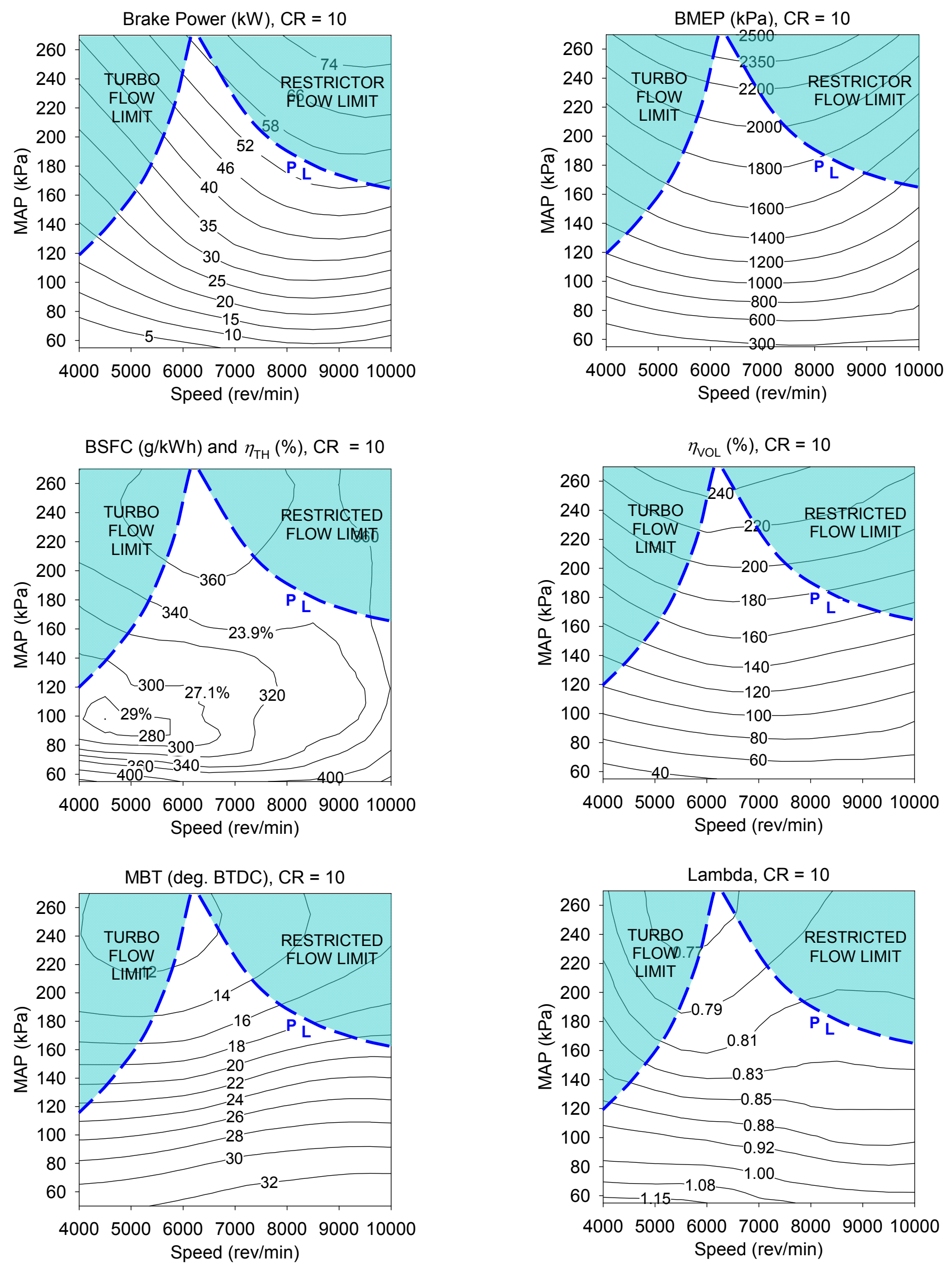

Figure 10: TC-PFI experimental results for brake power, BMEP, BSFC, $\eta_{\text {NOL }}$, spark timing and $\lambda$ with varying engine speed and MAP parameters, $C R=10$. $P L$ is the performance limit line defined at WOT. 
Emissions results for $\lambda$ variation closely follow previous published trends $[18,26,28,29]$, highlighting the emission formation's dependence on AFR. Hydrocarbon (HC) emissions are shown to decrease as power is increased due to the increased in-cylinder and/or exhaust burn-up due to the higher temperatures. $\mathrm{CO}_{2}$ emission contours mimic the BSFC as levels are proportional to the amount of fuel consumed, assuming all $\mathrm{HC}$ and carbon monoxide (CO) emissions are negligible or are oxidized to $\mathrm{CO}_{2}$.

Oxides of nitrogen $\left(\mathrm{NO}_{\mathrm{X}}\right)$ emission results are also shown in Figure 9, with peak formation occurring slightly lean of stoichiometric. Trends highlight that $\mathrm{NO}_{x}$ formation is highly dependent on combustion temperatures as accepted in the literature [18,28]. Consequently, $\mathrm{NO}_{x}$ emissions increase for rising MAP and hence power levels, with contours opposing $\mathrm{HC}$ levels due to the $\mathrm{HC}$ and $\mathrm{NO}_{x}$ tradeoff [18].
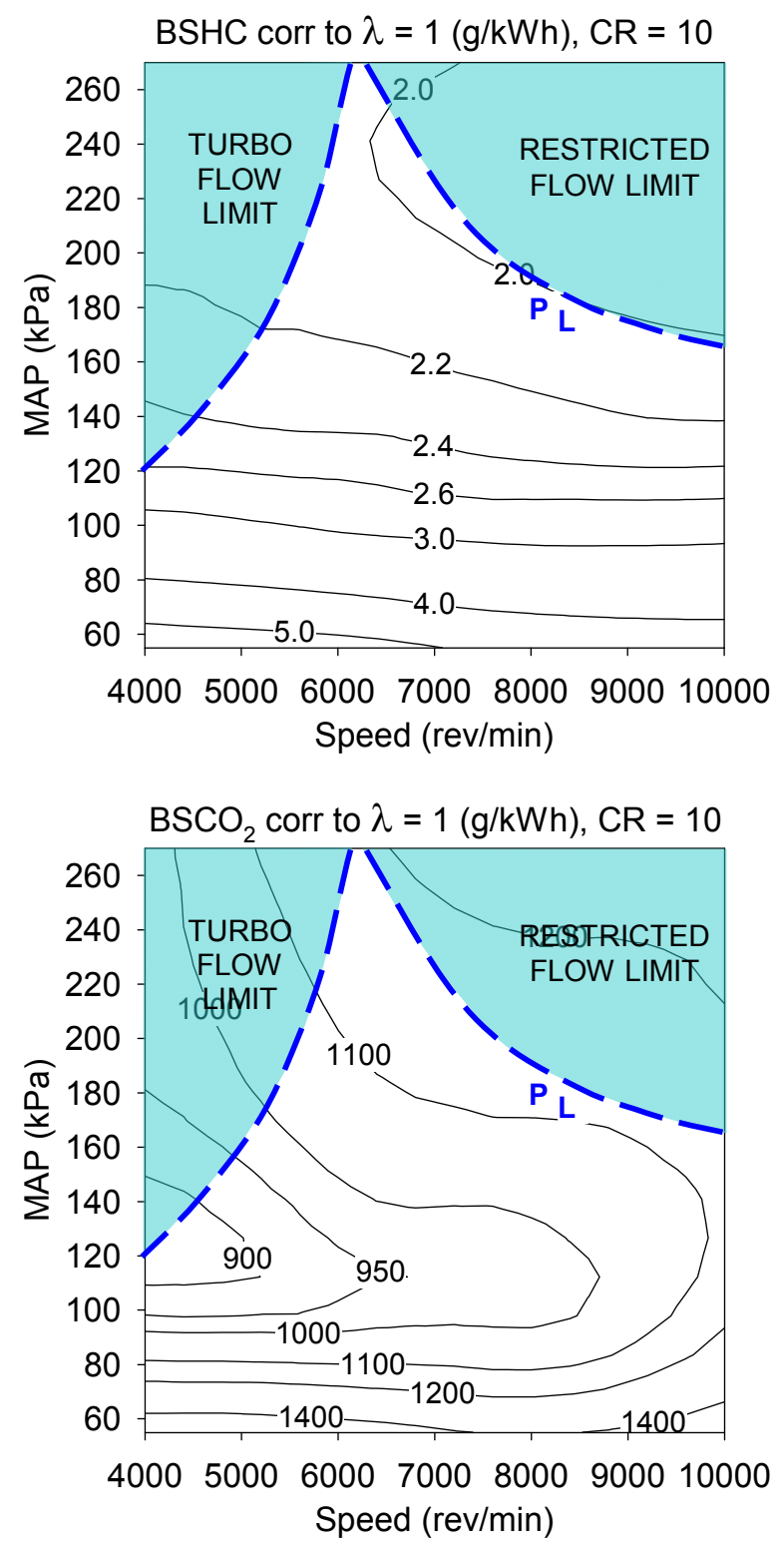

Figure 11: TC-PFI engine out brake specific emissions corrected to stoichiometric conditions for varying engine speed and MAP, $C R=10$.

\section{LARGER ENGINE COMPARISON}

To illustrate the potential of downsized engines in passenger vehicles, a preliminary feasibility study of replacing a 1.25 liter NA engine with a downsized boosted engine with similar brake power was completed. The downsized option used in comparisons is the test engine operating in the TC mode (optimized for the flow restricted condition, $C R=10$ ), with full and part load test data used in comparisons. The purpose of the comparisons is to determine if the performance of downsized engines can match larger counterparts and to find what fuel efficiency benefits and $\mathrm{CO}_{2}$ emission reductions are probable. The objective of these comparisons is to show that there are opportunities to improve engines found in the compact sized regular passenger vehicle class, thus highlighting the potential to downsize what are already considered small engines in today's marketplace.

The example taken for this comparison is a Ford 1.25 liter Duratec engine fitted to the 2007 Fiesta Mark VII series, with engine specifications given in Table 3 [30]. A summary of the Fiesta Duratec performance, efficiency and emissions data is given in Table $4[30,31]$. It is noted that the supplied data is for tests conducted using 95-RON pump gasoline compared to the 98-RON used in the test engine. The Ford Fiesta was chosen for comparison, being a leader in the small vehicle class in Europe with three decades of past and current dominance in the UK market [32]. The Duratec engine also shares design similarities when compared to the test engine.

If the smaller engine were to be installed into the Fiesta passenger vehicle, there are several foreseeable obstacles that would require attention. The main obstacle is the noise, vibration and harshness (NVH) due to the higher engine speeds and odd fire inline twin configuration. Also, higher exhaust backpressures due to the TWC may reduce turbocharger performance.

Table 3: Specifications for the Ford Duratec engine fitted to the 2007 Fiesta Mark VII series, used for comparison against the test engine.

\begin{tabular}{|c|c|}
\hline VEHICLE / ENGINE & 2007 Ford Fiesta / Duratec \\
\hline TYPE & $\begin{array}{l}\text { In-line } 4 \text { cylinder } \\
4 \text { stroke SI, } \\
\text { Liquid-cooled, } \\
\text { Aluminum head/ block }\end{array}$ \\
\hline CAPACITY & $1242 \mathrm{~cm}^{3}$ \\
\hline BORE x STROKE & $71.9 \times 76.5 \mathrm{~mm}$ \\
\hline COMPRESSION RATIO & $10: 1$ \\
\hline COMBUSTION CHAMBER & Pent roof central spark plug \\
\hline VALVE ACTUATION & 16-valve $\mathrm{DOHC}$ \\
\hline INDUCTION & NA sequential PFI \\
\hline FUEL & 95-RON pump gasoline \\
\hline EMISSION CONTROL & Closed-loop TWC, Euro IV \\
\hline
\end{tabular}


MAP (kPa) @ WOT

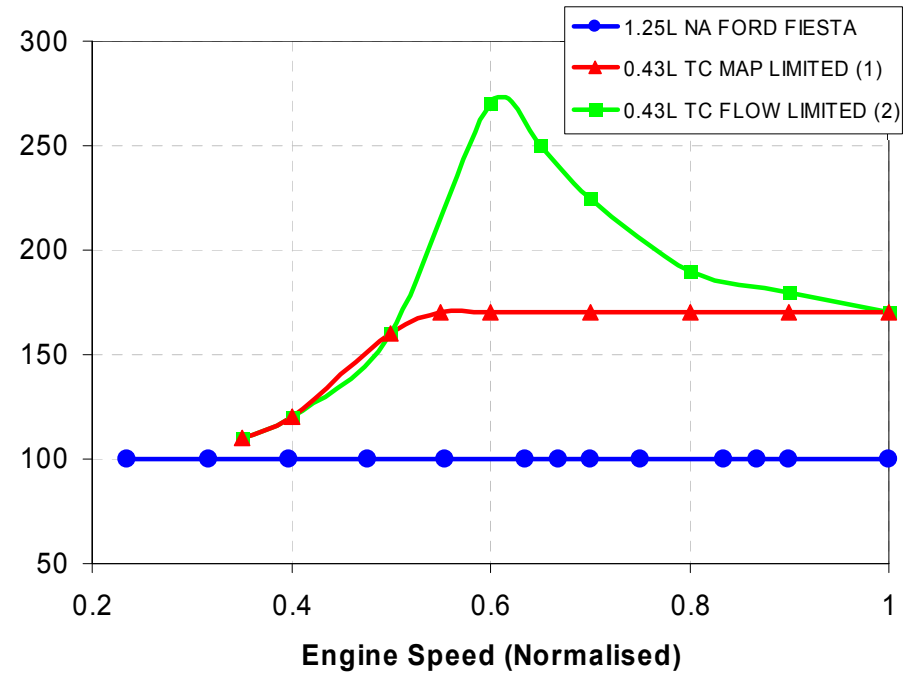

BMEP (kPa) @ WOT

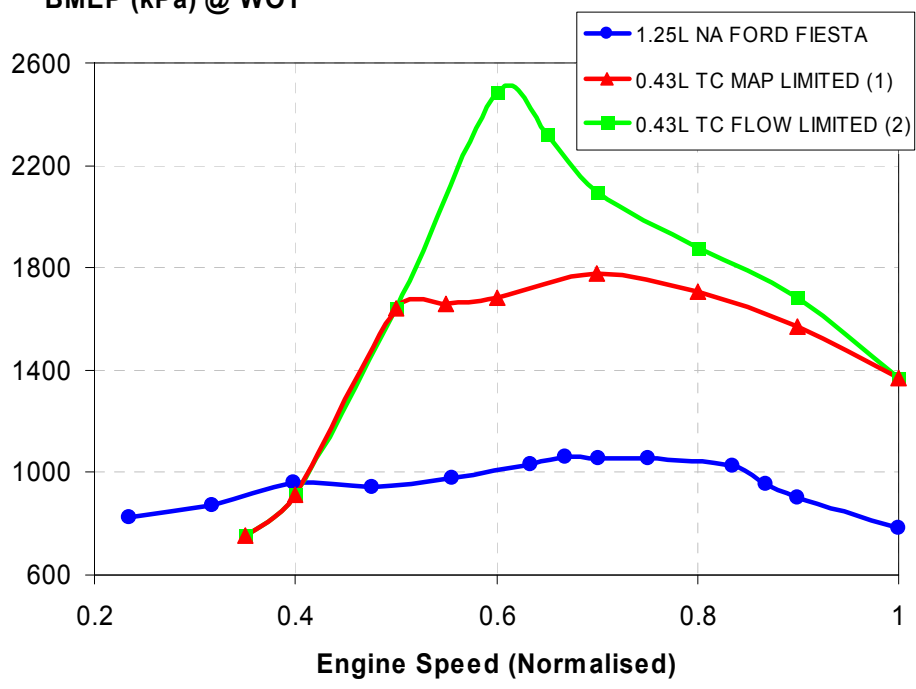

Brake Power (kW) @ WoT

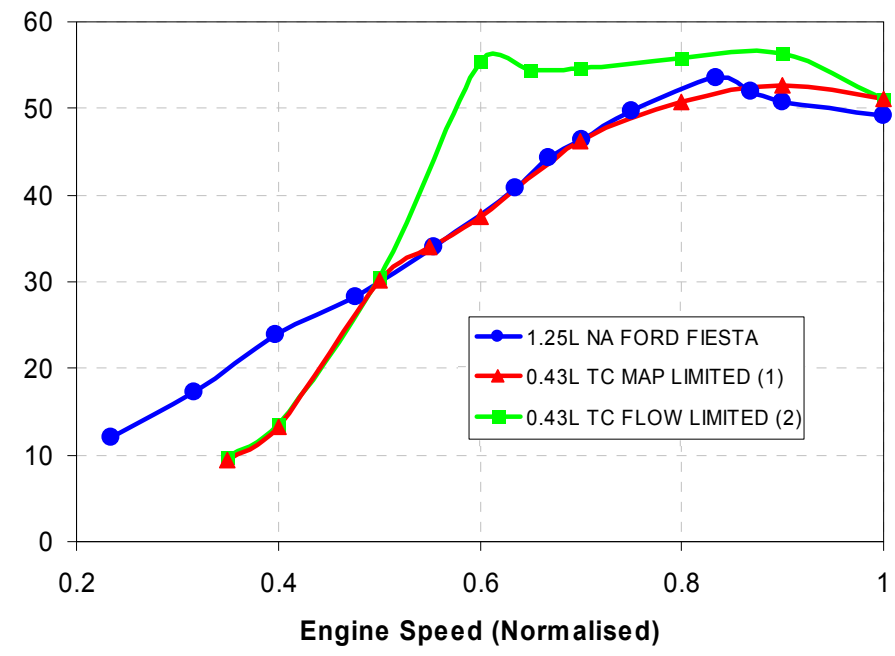

Figure 12: WOT performance comparison between the Ford Fiesta 1.25 liter NA engine and the smaller TC test engine used in experiments. (Top): MAP. (Middle): BMEP. (Bottom): Brake Power. Two performance curves are shown for the test engine; (1) Limited MAP by a wastegate (170 kPa)

(2) Limited airflow by an intake restriction $(\varnothing 20 \mathrm{~mm})$
However, emission control would most likely not be more difficult with the test engine as both engines share design similarities including matching fuel supply systems. The Fiesta exhaust after treatment (TWC) could be implemented to the test engine enabling both engines to meet Euro IV emission standards, when operating at stoichiometric conditions over the drive cycle. However, exhaust after treatment testing was out of the scope of the project.

\section{PERFORMANCE}

Figure 12 compares the WOT performance of both engines, achieved via normalizing the engine speeds to accommodate for the different speed ranges. Normalizing allows comparisons to be made, which could realistically be achieved through transmission or driveline ratios to obtain matching vehicle speeds.

Three WOT performance curves are shown in Figure 12, a baseline for the Ford Fiesta and two possible WOT operating conditions for the smaller test engine. It is noted that the test engine remained unchanged between both operating conditions with equal $C R$ and turbocharger systems. The varying operating conditions for the test engine are a result of different intake flow conditions, which include:

(1) Limited MAP by a wastegate (Maximum MAP $=170 \mathrm{kPa}$ )

(2) Limited airflow by an intake restriction (Intake restriction $=20 \mathrm{~mm}$ in diameter)

As previously described, the test engine was optimized for the limited airflow (2) condition, resulting in a CR of 10 and turbocharger matching to suit this condition. Hence, results presented for the limited MAP (1) condition could be further improved. However, the purpose of displaying two operating performance curves is to highlight the performance opportunities downsized engines can achieve. As can be seen from the middle diagram of Figure 12, the test engine recorded peak BMEP values of 25 bar, believed to be the highest specific output recorded for small engines operating on pump gasoline $[8,11,13,20]$. This performance was achieved at mid range engine speeds using $270 \mathrm{kPa}$ MAP for the limited airflow (2) condition. This equates to a 2.5 fold increase in peak BMEP when compared to the Fiesta engine. Consequently, the peak power of the Fiesta engine is matched or exceeded over both intake flow conditions, with a $66 \%$ reduction in swept capacity. The concept of achieving near constant power over a wide speed range is also shown for the limited airflow (2) condition, documented to improve vehicle drivability with a reduction in the required gearshifts [10].

WOT performance comparisons are also made across the normalized speed range, as peak power is seldom used in general driving patterns as demonstrated by the drive cycle time frequency distribution of Figure 13 $[1,33]$. The MAP limited (1) smaller test engine, with 0.7 bar boost is shown to match or exceed Fiesta brake power over half the normalized speed range. However, Fiesta power is not met at low engine speeds due to the 
turbocharger's inability to supply the required boost to increase performance. The smaller engine's lack of low speed performance could be overcome with improved turbocharger matching, as the system was optimized for the limited airflow (2) intake condition. Dual scroll or variable turbine geometry (VTG) $[4,16,17,34]$ could also be implemented to improve low speed performance. Furthermore, the vehicle transmission could be designed with changes to match the reduced engine inertia. This could include higher first gear ratios in manual transmissions or higher rates of clutch/torque converter slip for direct shift gearboxes (DSG) and automatic transmissions to accommodate the reduced low speed performance. Whichever strategy is used, some compromises are needed to give good driving feel in the low speed WOT domain, which is commonly used in initial vehicle acceleration.

\section{FUEL CONSUMPTION AND $\mathrm{CO}_{2}$ EMISSIONS}

Fuel consumption and resulting $\mathrm{CO}_{2}$ emissions are also compared between both engines. It is noted that $\mathrm{CO}_{2}$ levels are calculated via fuel consumption, which assumes all fuel carbon consumed by the vehicle is converted into $\mathrm{CO}_{2}$. This method is representative of actual tail pipe $\mathrm{CO}_{2}$ emissions caused by either the engine or exhaust oxidization using after treatment. This after treatment involves largely converting engine out $\mathrm{CO}$ and $\mathrm{HC}$ emissions into $\mathrm{CO}_{2}\left(\mathrm{CO} \rightarrow \mathrm{CO}_{2}, \mathrm{HC} \rightarrow \mathrm{CO}_{2}\right)$, needed to reduce emission concentrations to acceptable limits.

Table 4: Possibilities of adapting the smaller test engine into the Fiesta chassis and the effects on vehicle performance, fuel consumption and $\mathrm{CO}_{2}$ emissions against the standard OEM vehicle.

\begin{tabular}{|c|c|c|}
\hline & \multicolumn{2}{|c|}{$\begin{array}{c}\text { ENGINE COMPARISONS } \\
\text { (2007 FORD FIESTA CHASSIS) }\end{array}$} \\
\hline & $\begin{array}{c}\text { Duratec } \\
\text { (Standard OEM) }\end{array}$ & $\begin{array}{c}\text { UniMelb 'WATTARD' } \\
\text { (retro-fitted) }\end{array}$ \\
\hline Capacity & $1.25 \mathrm{~L}$ & $0.43 \mathrm{~L}$ \\
\hline Configuration & Inline 4 cylinder & Inline 2 cylinder \\
\hline Induction & NA - PFI & $\begin{array}{c}\text { TC - PFI } \\
\text { 170kPa MAP limit (1) }\end{array}$ \\
\hline $\begin{array}{l}\text { Mass } \\
\text { Vehicle (kerb) } \\
\text { Powertrain }\end{array}$ & $\begin{array}{c}1096 \mathrm{~kg} \\
180 \mathrm{~kg}\end{array}$ & $\begin{array}{l}\text { See Table } 5 \\
\quad 84 \mathrm{~kg}\end{array}$ \\
\hline $\begin{array}{l}\text { Performance } \\
\text { Max. Power } \\
\text { Max. Torque }\end{array}$ & $\begin{array}{c}(95-\mathrm{RON}) \\
55 \mathrm{~kW}-5200 \mathrm{r} / \mathrm{min} \\
110 \mathrm{Nm}-4000 \mathrm{r} / \mathrm{min}\end{array}$ & $\begin{array}{c}(98-R O N) \\
53 \mathrm{~kW}-9000 \mathrm{r} / \mathrm{min} \\
63 \mathrm{Nm}-7000 \mathrm{r} / \mathrm{min}\end{array}$ \\
\hline $\begin{array}{l}\text { Fuel Consumption* } \\
\text { Idle } \\
\text { Urban } \\
\text { Extra Urban } \\
\text { Combined (NEDC) }\end{array}$ & $\begin{array}{c}0.8 \mathrm{~L} / \mathrm{hr}-800 \mathrm{r} / \mathrm{min} \\
8.2 \mathrm{~L} / 100 \mathrm{~km} \\
4.7 \mathrm{~L} / 100 \mathrm{~km} \\
6.0 \mathrm{~L} / 100 \mathrm{~km}\end{array}$ & $\begin{array}{c}0.3 \mathrm{~L} / \mathrm{hr}-1000 \mathrm{r} / \mathrm{min} \\
- \\
- \\
\text { Table } 5\end{array}$ \\
\hline $\begin{array}{l}\mathrm{CO}_{2} \text { Emissions* } \\
\text { Idle } \\
\text { Combined (NEDC) }\end{array}$ & $\begin{array}{l}1.9 \mathrm{~kg} / \mathrm{hr} \\
142 \mathrm{~g} / \mathrm{km}\end{array}$ & $\begin{array}{l}0.7 \mathrm{~kg} / \mathrm{hr} \\
\text { Table } 5\end{array}$ \\
\hline
\end{tabular}

${ }^{*}$ EEC Directive 1999/100/EC
Comparisons between both engines for equal power outputs near WOT show that the larger displacement NA engine has a fuel consumption advantage for equal CRs due to the reduced levels of fuel enrichment and spark retard needed to control knock [14]. At reduced load conditions, the smaller TC engine shows a reduction in BSFC due to the improved mechanical efficiency associated with the greatly reduced pumping losses.

The effects at idle conditions and over the NEDC are also investigated, with comparisons assuming the test engine is fitted to the Fiesta chassis as outlined in Table 4. At idle speeds, a $62 \%$ reduction in fuel consumption, and hence $\mathrm{CO}_{2}$ emissions, is recorded for the smaller test engine. Vehicle mass out emissions are also reduced by a similar magnitude due to the engine size, prior to catalyst light-off. Start up emissions contribute a significant minority of emissions in heavily populated areas, thus highlighting the potential for this type of powertrain in these areas.

\section{Combined (NEDC)}
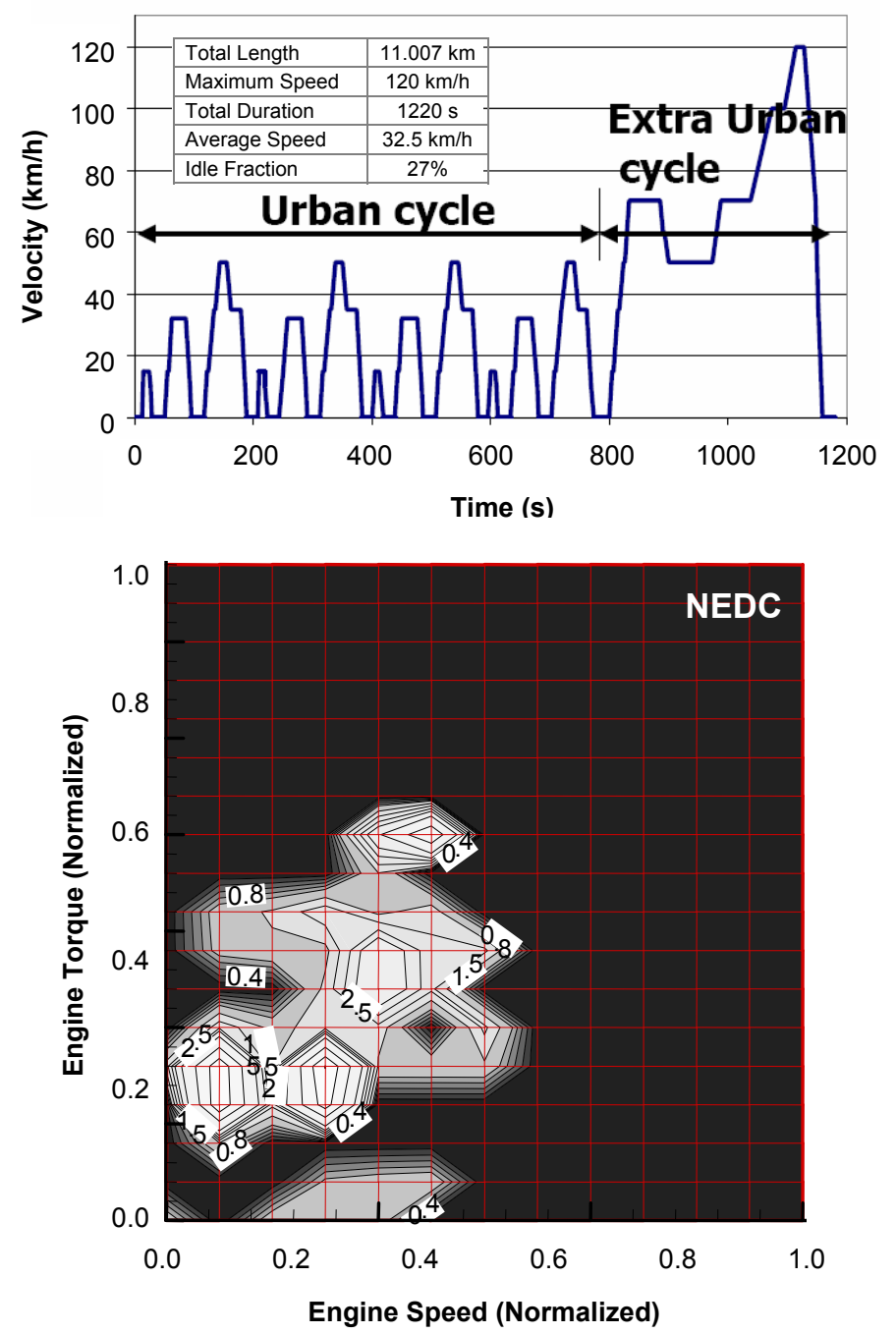

Figure 13: NEDC operating points for the Ford Fiesta chassis, used to compare fuel consumption and $\mathrm{CO}_{2}$ emissions for the OEM 1.25 liter NA engine and the smaller 0.43 liter TC test engine used in experiments. (Top): Combined Urban and Extra Urban drive cycle forming the NEDC [1]. (Bottom): Generated time frequency distribution for the NEDC [33]. 
Idle benefits are caused by the smaller engine's ability to run at lower mean piston speeds (MPS). A minimum MPS of $1.9 \mathrm{~m} / \mathrm{s}$ corresponding to $1000 \mathrm{rev} / \mathrm{min}$ was achieved while still maintaining adequate idle stability $[35,36]$. Lower idle speeds are achievable with further development, which would further reduce fuel consumption and emissions. However, this is dependent on fuel injectors with an improved turn-down ratio to improve combustion stability $[18,37]$. Other factors include the crankshaft velocity and vibration effects due to the unequal firing spacing of the inline twin configuration. Hence, it is doubtful that the larger engine's idle speed of $800 \mathrm{rev} / \mathrm{min}$ could be matched, without balancing improvements attainable with further development.

Quasi-steady analysis is now reported for the Euro NEDC for both engines, with the test cycle characterized by an urban/extra-urban driving mix. Vehicle and corresponding engine operating points are given in Figure 13 [1,33], which displays the torque-speed, time frequency distribution for the NEDC. The vehicle transmission is assumed adjusted so that both engines produce matching vehicle speeds, thus allowing engine speed normalization over the drive cycle frequency matrix. Consequently, a downside not clearly seen due to the speed normalization is the smaller engine's increased speeds over the drive cycle. The increased engine speeds increase friction losses and hence increase fuel consumption, highlighting the potential for further improvements if engine speeds can be reduced.

A fuel consumption advantage as a consequence of installing the smaller engine into the Fiesta chassis is caused by the reduced vehicle mass, with the effects analyzed in Table 5.
Three configurations are analyzed, as listed:

(A) No change in vehicle mass

(B) Reduced vehicle mass due to the smaller engine's mass

(C) Reduced vehicle mass due to engine and chassis mass changes

Vehicle mass effects due to the engine (Configuration $B$ ) are based on values listed in Table 4, resulting in an approximate $100 \mathrm{~kg}$ reduction. This is primarily caused by halving the number of cylinders. However, further vehicle mass reductions are also achievable (Configuration $\mathrm{C}$ ) due to the possible chassis weight reduction to support the smaller engine after redesign. This involves repackaging the front of the vehicle to suit the smaller engine. However, accurately quantifying the reduction is difficult, with estimations based on empirical data [38].

A consequence of reducing the vehicle mass is the effect on road power required to maintain the correct vehicle speed over the NEDC. These effects are based on previous data [38] and are documented in Table 5. It is noted that reducing the vehicle mass by $10 \%$ correlates to only a $5 \%$ reduction in the required road power. Furthermore, equal reductions in road power do not correspond to equal fuel savings. This is due to the higher throttling needed to produce less road power for a fixed vehicle speed. The lower MAP causes higher pumping losses and hence engine operation at a reduced efficiency point. This effect is not as prevalent in TC engines because engine operation is at points where pumping losses are already low, resulting in only minor changes in engine efficiency over the drive cycle.

Table 5: Vehicle comparisons for several configurations involving the Fiesta chassis fitted with both OEM and smaller engines. The effects of vehicle mass on the power required to drive the vehicle at equal speeds over the NEDC and the resulting effects on fuel consumption and $\mathrm{CO}_{2}$ emissions.

\begin{tabular}{|c|c|c|c|c|c|}
\hline & \multicolumn{5}{|c|}{ Vehicle Configuration } \\
\hline & $\begin{array}{c}\text { Baseline } \\
\text { OEM production } \\
\text { Fiesta } \\
\text { (NA 1.25L) }\end{array}$ & $\begin{array}{c}(\mathrm{A}) \\
\text { Fiesta chassis } \\
\text { with smaller } \\
\text { engine } \\
\text { (TC } 0.43 \mathrm{~L}) \\
\text { (No vehicle mass } \\
\text { reduction) }\end{array}$ & $\begin{array}{c}(\mathrm{B}) \\
\text { Fiesta chassis } \\
\text { with smaller } \\
\text { engine } \\
\text { (TC } 0.43 \mathrm{~L} \text { ) } \\
\text { (Vehicle mass } \\
\text { reduction due to } \\
\text { engine only) }\end{array}$ & $\begin{array}{c}(\mathrm{C}) \\
\text { Modified Fiesta } \\
\text { chassis with } \\
\text { smaller engine } \\
\text { (TC } 0.43 \mathrm{~L} \text { ) } \\
\text { (Vehicle mass } \\
\text { reduction due to } \\
\text { engine and } \\
\text { chassis) }\end{array}$ & $\begin{array}{c}\left(\mathrm{C}_{\lambda=1}\right) \\
\text { Modified Fiesta } \\
\text { chassis with } \\
\text { recalibrated engine } \\
\text { (TC } 0.43 \mathrm{~L}) \\
\text { (Vehicle mass } \\
\text { reduction due to } \\
\text { engine and } \\
\text { chassis, } \lambda=1 \text { ) }\end{array}$ \\
\hline Vehicle Mass & $1096 \mathrm{~kg}$ & $1096 \mathrm{~kg}$ & $1000 \pm 20 \mathrm{~kg}$ & $900 \pm 50 \mathrm{~kg}$ & $900 \pm 50 \mathrm{~kg}$ \\
\hline Vehicle mass reduction & NA & 0 & $96 \pm 20 \mathrm{~kg}$ & $196 \pm 50 \mathrm{~kg}$ & $196 \pm 50 \mathrm{~kg}$ \\
\hline Road Power Required [38] & $\mathrm{y}$ & $y$ & 0.95 y & 0.89 y & $0.89 y$ \\
\hline Fuel Consumption (NEDC) & $6.0 \mathrm{~L} / 100 \mathrm{~km}$ & *5.4 L/100 km & *5.2 L/100 km & *4.9 L/100 km & $* * 4.7 \mathrm{~L} / 100 \mathrm{~km}$ \\
\hline $\mathrm{CO}_{2}$ Emissions (NEDC) & $142 \mathrm{~g} / \mathrm{km}$ & $128 \mathrm{~g} / \mathrm{km}$ & $123 \mathrm{~g} / \mathrm{km}$ & $116 \mathrm{~g} / \mathrm{km}$ & $111 \mathrm{~g} / \mathrm{km}$ \\
\hline Fuel consumption $\& \mathrm{CO}_{2}$ benefit & Baseline & $10 \%$ & $14 \%$ & $19 \%$ & $22 \%$ \\
\hline
\end{tabular}

$y=$ power required to maintain equal vehicle speeds over the NEDC

${ }^{*}$ Fuel consumption from raw experimental results (Figure 10)

** More accurate calibration to stoichiometric conditions (calculated) 
Further fuel saving potential also exists as experiments were conducted with varying $\lambda$ (Figure 10) due to the intended Formula application. Hence, more accurate calibration to stoichiometric conditions would produce fuel and emission benefits, as shown in Table 5 (Configuration $\mathrm{C}_{\lambda=1}$ ). Recalibration is also required for efficient TWC operation over the drive cycle. It is also noted that the engine was optimized for the limited airflow (2) intake condition with MAP values reaching $270 \mathrm{kPa}$, resulting in a CR of 10 . Hence, the potential exists to increase the CR as MAP values would not need to exceed $170 \mathrm{kPa}$ in order to match the OEM Fiesta performance for the intended application. An increase in CR would improve engine efficiency, as documented for this particular engine $[8,14]$. As further improvements are possible, Table 5 serves only as a guide to determine the feasibility of replacing the larger engine with the smaller option.

It can be concluded from Table 6 that a $22 \%$ reduction in fuel consumption and $\mathrm{CO}_{2}$ over the NEDC may be achievable by implementing the smaller engine into the Fiesta chassis. The result is attributed to a combination of factors, including engine operation at higher efficiencies and vehicle mass reductions. The efficiency benefits are associated with operating the smaller TC engine at higher MAP when compared to the larger engine, which reduces pumping losses and improves mechanical efficiency [18]. Hence, the smaller TC engine operates closer to peak efficiency over the NEDC which results in reduced fuel consumption, even though both engines produce similar peak efficiencies $(\approx 30 \%)$.

Table 6: Summary of fuel consumption and $\mathrm{CO}_{2}$ emission benefits arising from replacing the larger 1.25 liter NA OEM engine found in the Ford Fiesta with the smaller 0.43 liter TC test engine. Results compiled from Tables 4 and 5.

\begin{tabular}{|l|c|}
\cline { 2 - 2 } \multicolumn{1}{c|}{} & $\begin{array}{c}\text { Relative fuel consumption } \\
\text { and } \mathrm{CO}_{2} \text { reduction }\end{array}$ \\
\hline At Idle & $62 \%$ \\
Over the NEDC & $22 \%$ \\
\hline
\end{tabular}

\section{CONCLUSIONS}

The feasibility of replacing larger engines found in compact sized regular passenger vehicles with smaller engines $\left(\sim 500 \mathrm{~cm}^{3}\right)$ has been investigated in this paper. In particular, the effects on performance, efficiency and emissions have been analyzed for a 0.43 liter prototype engine across varying parameter domains. Experimental results show that the performance of the downsized engine can match larger counterparts, with peak BMEP values of 25 bar achieved, believed to be the highest recorded for small engines while operating on pump gasoline. However, experiments highlighted that spark knock prevented optimized combustion and was the most dominant factor in limiting the performance of this downsized engine.
A case study was performed to determine the feasibility of replacing a larger 1.25 liter NA engine found in the 2007 Ford Fiesta. Results show that the performance of the larger engine could be readily matched with the smaller TC unit, with a $66 \%$ reduction in engine capacity while using no complex knock preventative methods. This indicates the potential for the swept capacity of all NA engines fitted to automobiles to be halved with no loss in performance.

Analysis performed when assuming the downsized test engine is fitted to the Fiesta chassis shows a $22 \%$ reduction in fuel consumption and $\mathrm{CO}_{2}$ emissions over the NEDC, including the reduction to $62 \%$ at idle conditions. These benefits over the NEDC are shown to be a consequence of operating the test engine closer to peak efficiency, together with engine and chassis mass reductions. The reduction in $\mathrm{CO}_{2}$ would shift the vehicle well under (15\%) the 2012 Euro target of $130 \mathrm{~g} / \mathrm{km}$.

Hence, using downsized SI engines has many advantages over larger powertrains as described in this paper. Most importantly, the engine and turbocharger technology already exists in the marketplace, making downsized engines in passenger cars realizable. This has near term advantages in reducing vehicle running costs together with $\mathrm{CO}_{2}$ emissions, as concerns over global warming escalate.

\section{ACKNOWLEDGMENTS}

The public domain Ford data that was used for comparative purposes is acknowledged. The first author would like to thank the James Herbert Mirams trust for their postgraduate study support. The authors are also thankful for the patience, support and understanding of family, friends and generous sponsors who made the UniMelb 'WATTARD' engine possible.

$\begin{array}{ll}>\text { ACL Bearing Company - } & \text { Tas, Australia } \\ >\text { APEP Pistons - } & \text { Vic, Australia } \\ >\text { Argo Engineering - } & \text { NSW, Australia } \\ >\text { Bishop Innovation - } & \text { NSW, Australia } \\ >\text { Bohler Uddeholm - } & \text { Vic, Australia } \\ >\text { CadCore Pty Ltd - } & \text { Vic, Australia } \\ >\text { Concentric Asia Pacific - } & \text { SA, Australia } \\ >\text { Davies Craig - } & \text { Vic, Australia } \\ >\text { Electromold - } & \text { Vic, Australia } \\ >\text { Garrett Honeywell - } & \text { NSW, Australia } \\ >\text { Magnesium Technologies - } & \text { Vic, Australia } \\ >\text { MAME Centre for Manufacturing - } & \text { Vic, Australia } \\ >\text { M\&W Ignitions - } & \text { NSW, Australia } \\ >\text { Penrite Lubricants - } & \text { Vic, Australia } \\ >\text { QMI Solutions - } & \text { QId, Australia } \\ >\text { Ricardo - } & \text { Sussex, UK } \\ >\text { Robert Bosch - } & \text { Vic, Australia } \\ >\text { Siemans VDO - } & \text { Vic, Australia } \\ >\text { Southside Cylinder Heads - } & \text { Vic, Australia } \\ >\text { University of Melbourne - } & \text { Vic, Australia } \\ >\text { Wade Camshafts - } & \text { Vic, Australia } \\ >\text { Whitehorse Industries - } & \text { Vic, Australia }\end{array}$




\section{NOMENCLATURE}

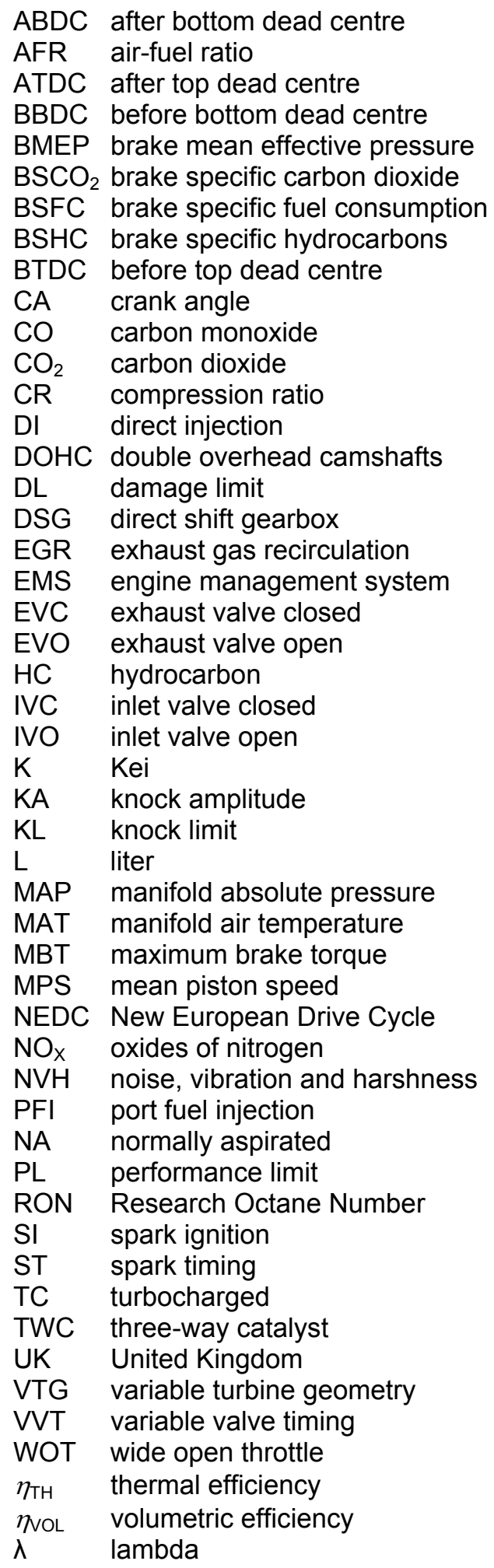

\section{REFERENCES}

1. http://www.dieselnet.com/standards/us/ca_ghg.php (2007)

2. PETITJEAN, D., BERNARDINI, L., MIDDLEMASS, C. and SHAHED, S.M., 'Advanced Gasoline Engine Turbocharging Technology for Fuel Economy Improvements', SAE paper 2004-01-0988. (2004)
3. LAKE, T., STOKES, J., MURPHY, R., OSBORNE, R. and SCHAMEL, A., 'Turbocharging Concepts for Downsized DI Gasoline Engines', SAE paper 200401-0036. (2004)

4. LECOINTE, B. and MONNIER, G., 'Downsizing a Gasoline Engine Using Turbocharging with Direct Injection', SAE paper 2003-01-0542. (2003)

5. ECKER, H.J., GILL, G. and SCHWADERLAPP, M., 'Downsizing of Diesel Engines: 3-Cylinder/4Cylinder', SAE paper 2000-01-0990. (2000)

6. KEPPELER, S., SCHULTE, H. and ECKER. H.J., 'The Technical Ramifications of Downsizing HSDI Diesel Technology to the 300cc Displacement Class', SAE paper 981916. (1998)

7. http://www.smartaustralia.com.au (2007)

8. ATTARD, W.P., 'Exploring the Limits of Spark Ignited Small Engines', Current Ph.D. Thesis, Mech. Eng. Dept., Univ. of Melbourne. (2007)

9. ATTARD, W.P., WATSON, H.C. and STRYKER, P., 'Design and Development of a Gasketless Cylinder Head/Block Interface for an Open Deck, Multi Cylinder, Highly Turbocharged Small Engine', SAE paper 2006-32-0036. (2006)

10. ATTARD, W.P. and WATSON, H.C., 'Development of a 430cc Constant Power Engine for FSAE Competition', SAE paper 2006-01-0745. (2006)

11. ATTARD, W.P., WATSON, H.C. and KONIDARIS, S., 'Highly Turbocharging a Restricted Two Cylinder Small Engine - Turbocharger Development', SAE paper 2007-01-1567. (2007)

12. ATTARD, W.P., WATSON, H.C. and KONIDARIS, S., 'Comparing the Performance and Limitations of a Downsized Formula SAE Engine in Normally Aspirated, Supercharged and Turbocharged Modes', SAE paper 2006-32-0072. (2006)

13. ATTARD, W.P, WATSON, H.C. and KONIDARIS, S., 'Highly Turbocharging a Restricted, Odd Fire, Two Cylinder Small Engine - Design, Lubrication, Tuning and Control', SAE paper 2006-01-3637. (2006)

14. ATTARD, W.P., KONIDARIS, S., HAMORI, F., TOULSON, E. and WATSON, H.C., 'Compression Ratio Effects on Performance, Efficiency, Emissions and Combustion in a Carbureted and PFI Small Engine', SAE paper 2007-01-3623. (2007)

15. CAIRNS, A., BLAXILL, H., IRLAM, A., Exhaust Gas Recirculation for Improved Part and Full Load Fuel Economy in a Turbocharged Gasoline Engine', SAE paper 2006-01-0047. (2006)

16. MacINNES, H., 'Turbochargers', HP Books, ISBN 0912656-49-2. (1984) 
17. WATSON, N. and JANOTA, M.S., 'Turbocharging the Internal Combustion Engine', Macmillan Press, ISBN 0-333-242904. (1982)

18. HEYWOOD, J., 'Internal Combustion Engine Fundamentals', ISBN 007028637X. (1988)

19. ROTHE, M., HEIDENREICH, T., SPICHER, U. and SCHUBERT, A., 'Knock Behavior of SI Engines: Thermodynamic Analysis of Knock Onset Locations and Knock Intensities', SAE paper 2006-01-0225. (2006)

20. Automotive Engineering International, 'Traveling the Long Road to Gasoline Direct Injection', SAE International, June. (2006)

21. ROSENKRANZ, H.G., WATSON, H.C., BRYCE, W. and LEWIS, A. 'Driveability fuel consumption and emissions of 1.3 litre turbocharged spark ignition engine developed as a replacement for a 2 litre normally aspirated engine.' Proc. I.Mech.E., C118/86:139-150 pp. (1986)

22. GERTY, M., and HEYWOOD, J. B., 'An Investigation of Gasoline Engine Knock Limited Performance and the Effects of Hydrogen Enhancement', SAE paper 2006-01-0228. (2006)

23. SCHNEIDER, E.W. and BLOSSFELD, D.H., 'Effect of Break-In and Operating Conditions on Piston Ring and Cylinder Bore Wear in Spark-Ignition Engines', SAE paper 2004-01-2917. (2004)

24. OTOBE, Y., GOTO, O., MIYANO, H., KAWAMOTO, M., AOKI, A. and OGAWA, T., 'Honda Formula 1 Turbocharged V6 1.5 liter Engine', SAE paper 890877. (1989)

25. NAKAMURA, Y., 'Small High Speed, High Performance Gasoline Engine', SAE paper 640664. (1964)

26. TAYLOR, C.F., 'The Internal Combustion Engine in Theory and Practice', Vol. 1 and 2, ISBN 0262700271. (1977)

27. 'Motor Vehicle Emission Regulations and Fuel Specifications', Part 1, Summary and annual 1997/1998 update, Brussek CONCAWE, Report no. 9/98. (1998)

28. HEISLER, H., 'Advanced Engine Technology', ISBN 1560917342. (1995)

29. STONE, R., 'Introduction to Internal Combustion Engines', ISBN 0768004950. (1999)

30. http://www.ford.co.uk/ie/fiesta/fie_0508_spcdim/fie_0 508_spec/-/-/3/575336\# (2007)

31. http://www.rri.se (2007)

32. http://media.ford.com/newsroom/release_display.cf m?release $=25289(2007)$
33. KHAN, M., WATSON, H.C., BAKER, P.A., LIEW, G. and JOHNSTON, D., 'SI Engine Lean-Limit Extension Through LPG Throttle-Body Injection for Low CO2 and NOx', SAE paper 2006-01-0495. (2006)

34. KLEEBERG, H., TOMAZIC, D., LANG, O., and HABERMANN, K., 'Future Potential and Development Methods for High Output Turbocharged Direct Injected Gasoline Engines', SAE paper 2006-01-0046. (2006)

35. KHAN, M., WATSON, H.C., BAKER, P.A., LIEW, G. and JOHNSTON, D., 'Optimisation of LPG ThrottleBody Injection System for Improved Efficiency, Emissions and Air-Fuel Mixing', Fisita paper F2006P155. (2006)

36. BADAMI, M., MARZANO, M.R. and NUCCIO, P., 'Influence of Late Intake-Valve Opening on the S.I. Engine-Performance in Idle Condition', SAE paper 960586. (1996)

37. RUSS, S. and SCHOLL, D., 'Air-Fuel Ratio Dependence of Random and Deterministic Cyclic Variability in a Spark-Ignited Engine', SAE paper 1999-01-3513. (1999)

38. BEER, T., GRANT, T., WATSON, H.C. and OLARU, D., 'Life-Cycle Emissions Analysis of Fuels for Light Vehicles', Report HA93A-C837/1/F5.2E Australian Greenhouse Office. (2004)

\section{CONTACT}

William Attard

Thermofluids Group

Department of Mechanical Engineering

University of Melbourne,

Victoria, Australia, 3010

Email:william_attard@hotmail.com

Prof. Harry Watson

Head Thermofluids Group

Department of Mechanical Engineering

University of Melbourne

Victoria, Australia, 3010

Email: harrycw@unimelb.edu.au 


\section{University Library}

\section{- M M I N E R VA \\ A gateway to Melbourne's research publications}

Minerva Access is the Institutional Repository of The University of Melbourne

Author/s:

Attard, William;Konidaris, Steven;Toulson, Elisa;Watson, Harry

Title:

The feasibility of downsizing a 1.25 liter normally aspirated engine to a 0.43 liter highly turbocharged engine

Date:

2007

Citation:

Attard, W., Konidaris, S., Toulson, E., \& Watson, H. (2007). The feasibility of downsizing a 1.25 liter normally aspirated engine to a 0.43 liter highly turbocharged engine. In, Proceedings, SAE International ICE2007, 8th International Conference on Engines for Automobiles, Capri, Napoli, Italy.

Publication Status:

Published

Persistent Link:

http://hdl.handle.net/11343/34817 